\title{
Interest Rate Sensitivity in European Public Real Estate Markets
}

\author{
Alexey Akimov ${ }^{*}$ \\ Chyi Lin Lee ${ }^{\dagger}$ \\ Simon Stevenson ${ }^{\ddagger}$
}

\begin{abstract}
The importance of interest rates, in both financial markets and the broader economy, was clearly highlighted during and subsequent to the financial crisis of 2007-09. This paper examines the sensitivity of seven public real estate markets in Europe from 1995 to 2013. Europe is a particularly interesting market to look at in this context. Badly impacted during the financial crisis, it has been further affected by the sovereign debt crisis within the Eurozone. The introduction of the Euro and a single monetary policy within the Eurozone is a complicating factor that raises additional issues. The results highlight that, with one exception, the markets display significant sensitivity in terms of both returns and volatility. The results are, however, sensitive in both a temporal sense and to the interest rate-yield curve proxy used.
\end{abstract}

* This is the Authors' Original Manuscript of an article published in Journal of Real Estate Portfolio Management in June 2019, available online: https://www.tandfonline.com/eprint/ WUHV2RAG3IT2E2H4KDZ5/full?target=10.1080/10835547.2020.1803694

- Corresponding author: Department of Accounting 8 Finance, Lancaster University Management School, Bailrigg, Lancaster, LA14YX, UK; email: a.akimov@lancaster.ac.uk

$\dagger$ Department of Construction Management and Property, University of New South Wales, Penrith, NSW, Australia.

$\ddagger$ Runstad Department of Real Estate, University of Washington, Seattle, WA, USA. 


\section{Introduction}

Many of the events surrounding the 2007-09 financial crisis were in some way related to interest rates and the credit markets. This relationship was not simply concerned with the immediate impact of the credit crisis and the drying up of liquidity but also associated with a number of the factors preceding the crisis, including the relaxation of lending policies, that contributed to credit booms occurring in many markets. Furthermore, in response to the worsening economic climate post-2007, a loose monetary policy was widely implemented by many central banks. This not only involved the reduction of interest rates, but also quantitative easing. The relationship between interest rate changes and the asset markets has attracted a considerable degree of attention over the course of the last decade from investors, policy makers, and academics. This focus is enhanced by concerns over the impact on inflation, and thus, interest rates, following the exit from quantitative easing.

Many studies have examined the impact of monetary policy, generally, and interest rates, specifically, in the context of real estate. This literature, briefly reviewed below, includes a number of papers that consider the public real estate sector. However, it has primarily focused on the larger markets such as the U.S., U.K. and major Asian countries. This paper contributes to the literature in a number of areas. First, we extend the limited number of studies that have considered European markets other than the U.K. Given the growth in European public real estate, as witnessed through both the growth in market size and the introduction of dedicated traded futures contracts (Lee, Stevenson, and Lee, 2014), it is important that this gap in the body of research available be addressed. Of particular relevance is the presence of the Euro and a single monetary regime within the Eurozone. Secondly, European public real estate sectors have significantly different firm characteristics in terms of legal regime (REITs and non-REITs). Therefore, a dedicated analysis will assist investors in obtaining an enhanced understanding of whether real estate stocks with certain characteristics are more sensitive to interest rates. Finally, this is one of the first studies to examine the impact of the financial crisis and quantitative easing on the interest rate sensitivity of listed real estate vehicles. An in-depth understanding of interest rate sensitivity over different market conditions is critical in terms of investor decision-making. The results illustrate how, in the majority of markets considered, there is significant sensitivity to interest rates in terms of both return movements and volatility. Consistent with the existing literature, this sensitivity is both time-varying and sensitive to the interest rate maturity examined. This is also 
true when the entire yield curve is modeled. In this paper, we first briefly consider the existing literature. We then detail the data and present the baseline results, followed by an extended analysis that utilises yield curve models. Finally, we provide concluding comments.

\section{Literature Review}

As noted in the introduction, the events of the last decade have brought into sharp focus the importance of the credit markets and how interest rate dynamics can feed through and impact investment assets. In the specific context of equity markets, Bernanke and Kuttner (2005) highlight how interest rates can impact upon stocks in three ways: namely, the impact on expected future dividends, the discount rate, and the equity risk premium. The public real estate markets are an interesting sector to consider given the importance of both interest rates, specifically, and the macro-economy, generally, on the underlying property market and therefore the assets of the firms. The macroeconomic role interest rates have (Bernanke and Blinder, 1992) can provide an important channel through which both the cash flows and asset values of real estate firms can be affected. Economic conditions are one of the primary drivers behind rents and, consequently, corporate income. Additionally, interest rates influence property yields and asset values. Therefore, in a quite fundamental sense, interest rates are a key risk factor for real estate (Ling and Naranjo, 1997, Plazzi, Torous, and Valkanov, 2008).

In addition to this impact on the occupier and asset markets, there is also the more direct effect related to financing. Real estate firms, both REITs and corporates, use high degrees of leverage compared to companies in other industries (Bredin, O'Reilly, and Stevenson, 2007). This use of leverage is due to, and

influenced by, a variety of factors. Some of these are concerned with the nature of real estate as a high unit cost indivisible asset. Without debt, some investors may be effectively barred from entry into certain market sectors due to cost issues. The use of debt facilitates the purchase of properties of a higher value and accordingly, allows entry into high cost markets and property types. It also allows investors to buy more properties and increase their diversification potential. Investors may also benefit during strong markets from the positive impact that gearing can have on investment returns. Finally, given the small size of many real estate firms, there is often a cost-benefit in raising debt rather than equity.

These factors mean that not only do property companies use an extensive amount of debt, but REITs can, as well. This is the case even though REITs are 
tax transparent and do not have a tax advantage in issuing debt. Therefore, debt and equity capital are treated equivalently from a tax perspective. This use of debt naturally makes firms display potentially heightened sensitivity to interest rate movements. In addition to the above factors, the use of leverage alters a companyâ $€^{\mathrm{TM}} \mathrm{S}$ cost-of-capital and can therefore affect the future availability of external debt facilities. Subsequent interest rate changes and the interactions between firm investment and financing activities may be reflected accordingly in a companyâ $€^{\mathrm{TM}_{\mathrm{S}}}$ share price (Bernanke and Gertler, 1995). Finally, there is also the specific issue of the mandatory minimum dividend present in the majority of REIT markets. The high-yield status of REITs means that the impact of interest rate fluctuations on the present value of dividends is likely to be greater than in a non-REIT context (Bernanke and Kuttner, 2005). Lee and Stevenson (2005) also note how the high-yield status of REITs can introduce bond-like qualities into their investment dynamics and influence their potential role in a portfolio context.

Many studies have previously examined the effect of interest rate changes on the listed real estate market. These studies have adopted a variety of empirical approaches. Among those adopting multi-factor or GARCH time-series approaches, it has often been observed that the sensitivity is time-varying and dependent on the time period examined (Chen and Tzang, 1988, Liang, Mclntosh, and Webb, 1995, Swanson, Theis, and Casey, 2002, He, Webb, and Myer, 2003). A number of papers have also reported that REITs are predominantly exposed to long-term rates. For example, Devaney (2001) finds heightened sensitivity to 10-year government bond yields. Comparable results are also reported by Chen and Tzang (1988). While He et al. (2003) reach similar conclusions, they do note that the results may be sensitive to the interest rate proxy selected. Against this background, Allen, Madura, and Springer (2000) report significant sensitivity of REITs to both shortand long-term government bonds. Akimov, Stevenson, and Zagonov (2015) further illustrate the issues surrounding the choice of interest rate proxy in their analysis of the entire yield curve rather than a single proxy. Using a different methodological approach, Bredin et al. (2007) highlight the importance of analyzing unexpected changes in interest rates by utilizing the fed funds futures market as a measure of expectations. The empirical results show that monetary shocks have a strong impact on both U.S. REIT returns and volatility. Both Xu and Yang (2011) and Bredin, O'Reilly, and Stevenson (2011) expand upon these findings. Bredin et al. (2011) observe that monetary policy surprises have a consistent impact on U.S. REIT returns and that the key driver behind this influence is the dividend channel. Xu and Yang (2011) illustrate how U.S. monetary shocks impact overseas markets. This study, along with a recent analysis by Chang, Chen, and Leung (2013), is 
one of the few real estate-related papers to have considered how interest rates influence overseas markets.

In comparison to the relatively large number of papers that focus on the U.S. REIT market, the European listed sector has received very little attention in the academic literature. Two notable exceptions are Lizieri and Satchell (1997), and Stevenson, Wilson, and Zurbruegg (2007), who both consider the U.K. prior to the introduction of REITs in January 2007. Stevenson et al. (2007) analyze a sample period (1993-2005) characterized by low and stable interest rates, yet continue to find evidence of significant sensitivity to rate changes. Lizieri and Satchell (1997) find that the link between interest rates and real estate securities is sensitive to high- and low-interest rate regimes. Comparable evidence is also documented by Chang (2011) for the U.S. REIT market. In addition, Chang, Chen, and Leung (2011) employ a regime-switching model to examine the impact of changes in the monetary policy on U.S. Equity REITs, housing, and stock returns. The results suggest that the interest rate spread seems to amplify the effect on REIT returns.

\section{GARCH-M Framework Initial Empirical Results}

This paper examines the issue of interest rate sensitivity using a variety of GARCH (Generalized Autoregessive Conditional Heteroskedasticity) models. The advantage of using a GARCH framework over simpler factor models is that it allows the examination of interest rate sensitivity with respect to both returns and volatility. Furthermore, due to its ability to incorporate volatility clustering, especially in the GARCH-M specification adopted in this paper, it is ideally suited to the examination of daily data. The paper considers daily-basis data from the seven largest and longest-standing public real estate markets across Europe: Belgium, France, Germany, Netherlands, Sweden, Switzerland and the U.K.

These seven real estate markets comprise a mixture in the context of the Eurozone. Four of the markets joined the Euro at the point of its launch in 1998; namely, Belgium, France, Germany and the Netherlands. These markets not only swapped their own currencies (Belgium Franc, French Franc, Deutschmark, Dutch Guilder) for the Euro after this date, but also gave up independent monetary policies. The European Central Bank (ECB) sets a common monetary policy across the Eurozone. Therefore, post-1998, all four markets operate under the same interest rate regime. The remaining three markets are not members of the Eurozone. Sweden and the U.K. are members of the European Union but obtained opt-outs from the single currency. They continue to operate an independent 
monetary policy and have their own currencies, the Swedish Krona and Pound Sterling. Switzerland is neither a member of the EU or Eurozone. Therefore, it is interesting to consider whether the sensitivity of the different markets alters depending on membership in the EU or adoption of the single currency. The analysis is conducted over a sample period of 1990-2015, alongside two sub-periods (1990-2003 and 2004-2015). Table 1 reports summary statistics for the different markets.

\section{TABLE 1 HERE}

Following Elyasiani and Mansur (1998) and specific public real estate context papers such as Devaney (2001) and Stevenson et al. (2007), we adopt a GARCH-M specification. A basic GARCH-M process can be displayed as follows:

$$
\begin{gathered}
r_{t}=\gamma x_{t}+\delta h_{t}+\varepsilon_{t} \\
h_{t}=\alpha_{0}+\sum \alpha_{i} \varepsilon_{t-i}^{2}+\sum \beta_{j} h_{t-j}^{2} \\
\varepsilon_{t} \mid I_{t-1} \sim N\left(0, H_{t}\right)
\end{gathered}
$$

where Equation ((1)) models the conditional mean and Equation $((2))$ the conditional variance. This specification, therefore, models the returns of the real estate securities $(r)$ in relation to the vector of exogenous variables $(x)$ and its own conditional variance $(h)$. The variance equation models the conditional variance on both lagged squared errors $\left(\varepsilon^{2}\right)$ and a moving average of lagged conditional variances $\left(h^{2}\right)$. An advantage of the GARCH-M specification is that, in contrast to a basic GARCH $(1,1)$, it allows the risk-premia to vary, thus allowing for the effect of volatility clustering. It, therefore, effectively acknowledges that investors take into account the volatility of an asset when considering the risk premia that they seek.

The model specification used is similar to that adopted in papers such as Stevenson et al. (2007) and includes interest rate volatility directly in the variance equation. We incorporate the conditional variance of the exogenous variables used in the mean equation in the variance equation, as well. The final specification used can be displayed as follows:

$$
r_{i, t}=\mu_{0}+\delta_{1} h_{i, t}+\beta_{1} r_{i, t}^{M}+\beta_{2} i r_{i, t-1}+\varepsilon_{i, t}
$$




$$
\begin{gathered}
h_{i, t}=a_{0}+a_{1} \varepsilon_{i, t-1}^{2}+b_{1} h_{i, t-1}+g_{1} h_{i, t-1}^{M}+g_{2} h_{i, t-1}^{I R} \\
\varepsilon_{i, t} \mid \Omega_{i, t-1} \sim N\left(0, h_{i, t}\right)
\end{gathered}
$$

In this specification $r_{i}$ represents the returns for listed real estate market $i, r_{i}^{M}$ is the return of the appropriate market equity index and $i r$ is the respective interest rate series. The volatility equation is augmented by the respective conditional volatilities.

\section{TABLE 2 HERE}

Table 2 reports the results for the baseline GARCH-M model with market interest rates. Standard errors are corrected using the quasi-maximum likelihood procedure of Bollerslev and Wooldridge (1992). In general, we document weaker evidence of public real estate sensitivity to changes in market interest rates than the literature initially suggests. We find no significant results in the mean equation across the entire sample period for France, Germany, Netherlands or Switzerland. Sweden and the U.K. - both outside the Eurozone - are found to react to changes in the short-term rates, while Belgium is sensitive to the changes in 10-year interest rates, as well as the term spread. In the majority of cases, the results for 19952013 are supported by the later sub-sample period. Public real estate markets in Germany and the Netherlands are also found to be sensitive during the 2004-2013 sub-period. However, Germany displays a strong negative reaction to 3-month interest rates, while the Netherlands is positively affected by the 10-year rate. The results for Germany and the Netherlands are consistent with Lizieri and Satchell (1997) and Lizieri, Satchell, Worzala, and Dacco (1998), who report no sensitivity in either the U.S. or U.K. to interest rate changes during the periods of high volatility. In both countries interest rate volatility was lower during the 2004-2013 period. Stevenson et al. (2007) also document the significance of interest rates for listed real estate during a period of stable interest rates in the U.K. (1993-2005).

The conditional volatility coefficients of interest rates are estimated based on Equation ((5)). Generally, we document stronger evidence of the significance in comparison with the results for the mean equation. We find that the volatility of each of the public real estate markets, with the exception of Belgium and Switzerland, is affected by the conditional volatility of interest rates. However, only two markets react to interest rate volatility consistently, namely, the Netherlands and Sweden. Significance, in the cases of Germany, France and the U.K., appears only in our subsample analysis. Moreover, the coefficients vary in terms of both 
the sign and magnitude. For instance, we often observe an inverse reaction of public real estate volatility to heightened volatility of the interest rates: namely, the U.K. (3-months during 1995-2003, 10-year and term spread during 2004-2013); Sweden (10-year during 2004-2013); and the Netherlands (3-months, term spread during both 1995-2013 and 1995-2003). One possible explanation for the inverse relationship between the variance of listed real estate and the conditional volatility of interest rates lies behind the risk management practices used by the firms. Even if the majority of the companies in the sample attempt to hedge their interest rate risk, the hedging effectiveness might be more apparent when lower frequency data is used. The negative interest rate coefficient in the volatility equation can be taken as an indication of reduced future volatility clustering due to the arrival of new information. In other words, in the event of increased fluctuations in interest rates at time $t$, the information becomes absorbed very quickly by the market and calms the sector's variance in period $t+1$. The information regarding interest rate volatility may also reduce some proportion of the noise presented in the daily data, as our GARCH model treats the total measure of listed real estate sector risk and not its systematic component.

Overall, these findings are in contrast with those reported by Stevenson et al. (2007) for the U.K. However, there is no consistency in the evidence regarding the presence of a market within the Eurozone. Whereas quite consistent evidence is reported with respect to Sweden, which operates an independent monetary policy, the same is not true for the U.K. and especially Switzerland. However, such inconsistency is also noted within the Eurozone, with a wide range of results, with respect to both returns and volatility, across the four markets.

\section{Diebold, Piazzesi, and Rudebusch (2005) Yield Curve Model}

While the analysis contained in the preceding section does provide valuable insights about interest rate risk exposure it may still provide conflicting results with regards to the subjective choice of the interest rate proxy. As previously noted, studies such as He et al. (2003) highlight the potential sensitivity of results to the proxy selected. In addition, any choice will contain a necessarily arbitrary element. For example, interest rates of 1-month, 3-months, 6-months, and 12months are all likely to have common drivers and additionally are likely to be all regarded as short-term rates. Finally, due to the econometric issues that would result, different proxies cannot be used simultaneously in a single model. Litterman and Scheinkman (1991) illustrate that information about interest rates 
can be summarized using a small number of common factors concerning the yield curve; namely, the level, steepness, and curvature. Diebold et al. (2005) extend this analysis and argue that information about yields is underlined by the small number of sources of systematic risk implying a high correlation between different maturities.

Studies such as Swanson et al. (2002) overcome this issue by using a yield spread variable. However, such an approach implicitly assumes parallel shifts in the term structure. In contrast, we use Diebold and Li's (2006) dynamic version of the exponential components yield curve model of Nelson and Siegel (1987). This approach is used by Akimov et al. (2015) in their recent paper on seven global public real estate markets. A variety of papers (e.g. Diebold and Li, 2006, Fabozzi, Martellini, and Priaulet, 2005) have illustrated that the model provides a good fit of the term structure across a variety of monotonic, S-type and humped shapes typically observed in yield curve data. In addition, it captures information based upon the three yield curve parameters; namely, the level, slope and curvature. The Diebold and Li (2006) specification can be displayed as follows:

$$
y_{t}(\tau)=\beta_{1 t}+\beta_{2 t}\left(\frac{1-e^{-\lambda_{t} \tau}}{\lambda_{t} \tau}\right)+\beta_{3 t}\left(\frac{1-e^{-\lambda_{t} \tau}}{\lambda_{t} \tau}-e^{-\lambda_{t} \tau}\right)
$$

where $y_{t}(\tau)$ is the yield of a zero-coupon bond, with time-to-maturity $\tau$ at $t$. The respective beta coefficients represent the level, slope, and curvature of the yield curve respectively. $\lambda$ represents the exponential decay rate. The Nelson-Siegel model (1987) fits the term structure using a flexible, smooth parametric function based on a Laguerre function. As with any asset, the value of a stock can be viewed as being equal to the present value of future cash-flows. Therefore, it would be expected that a downward movement in rates, as captured by the level, should lead to higher prices. Given that short-term interest rates will be heavily influenced by Central Banks through inflation targets and the corresponding setting of prime rates (Mishkin, 1996, Reinhart and Simin, 1997) it would be anticipated that an inverse relationship would be observed with our proxy for short-term rates, the slope.

The empirical GARCH specification based upon the Diebold and Li (2006) yield curve model can be displayed as follows:

$$
\begin{gathered}
r_{i, t}=\mu_{0, i}+\beta_{1, i} L_{i, t}+\beta_{2, i} \hat{s}_{i, t}+\beta_{3, i} \hat{c}_{i, t}+\beta_{4, i} r_{i, t}^{M}+\varepsilon_{i, t} \\
\varepsilon_{i, t}=z_{i, t} \sigma_{i, t}
\end{gathered}
$$




$$
\sigma_{i, t}^{2}=a_{0, i}+a_{1, i} \varepsilon_{i, t-1}^{2}+b_{1, i} \sigma_{i, t-1}^{2}
$$

where $L_{i, t}, \hat{s}_{i, t}, \hat{c}_{i, t}$ denote the changes in the level, slope and curvature of the domestic zero-coupon yield curve respectively for market $i . z_{i, t}$ is a sequence of independent, identically distributed random variables zero mean and unit variance, implying $\varepsilon_{i, t} \mid \Phi_{i, t-1} \sim N\left(0, \sigma_{i, t}^{2}\right)$ is conditionally normal heteroskedastic error term, $\Phi_{i, t-1}$ is the information set available at time $t-1 . \sigma_{i, t}^{2}$ is the conditional variance of the listed real estate index returns at time $t$.

\section{TABLE 3 HERE}

The results are reported in Table 3. As before, in addition to the overall sample period we run the empirical tests using two sub-samples, year-end 2003 being the mid-point. For the full period of study, we find Belgium, Germany, Sweden, Switzerland and the U.K. are affected by at least one of the yield curve parameters. In the case of Sweden, all three factors are inversely related to public real estate returns at statistically significant levels of $5 \%$. We also document negative relationship between public real estate price changes and curvature in Belgium over the full sample period. The inverse relationship is as anticipated. Existing empirical evidence, which has documented an inverse relationship with rates of maturities ranging from 1 month to 20 years, would support this premise (e.g. Chen and Tzang, 1988, Devaney, 2001, Swanson et al., 2002, Stevenson et al., 2007). In two cases, Germany and the U.K., we find positive exposure to changes in level of the yield curve. However, this result is not robust to the sub-sample analysis. There are two additional results that reveal an unexpected positive sign. Switzerland is found to be exposed to positive changes in slope, while the impact of curvature on public real estate in Germany is significant in all three sub-periods.

Another finding that is quite noticeable is that the results across the two sub-samples differ quite substantially. There are no markets that were affected by the same yield curve factors throughout the sub-sample analysis. For instance, the aforementioned result for Sweden is found to be mainly driven by the 1995-2003 period where we document similar exposures to changes in the yield curve. The same yield curve factors are, however, insignificant when we consider the 2004-2013 sub-period. The time-varying nature of the interest rate sensitivity reported is consistent with Devaney (2001) and Stevenson et al. (2007). Overall, our findings highlight the advantages that may arise by going beyond the modeling of a single interest rate factor. Our Wald test results shown in Table 3 largely support this notion. These $\chi^{2}$-statistics test for the joint significance of the interest rate factors 
(i.e., $\beta_{1, i}=\beta_{2, i}=\beta_{3, i}=0$ ). Additionally, the results are consistent with the general theoretical formulation of the relationship between stocks, REITs and interest rates. However, it would be hard to describe the results as homogeneous, which is not surprising given the structural and legal differences across the markets considered.

\section{TABLE 4 HERE}

To examine impact of the term structure of interest rates on the volatility of public real estate we extend the initial GARCH specification in two alternative ways. Firstly, the volatility equation is augmented with one-period lagged changes in the level, slope, and curvature factors. Secondly, we replace the lagged factor changes with their respective conditional volatilities. The results are reported in Table 4. It is evident that in many instances, volatility is negatively affected by changes in the yield curve factors (e.g., France, Germany, the Netherlands, Switzerland and the U.K.). This would suggest that changes in the yield curve factors translate into lower volatility of listed real estate returns in the subsequent period. Effectively, there is less volatility clustering since the markets adjust their expectations more efficiently using information from the money markets. The impact of the interest rate variables on volatility is stronger over the longer sample period (i.e., 1995-2013) with most of the significant findings observed. However, this result is not robust to the sub-sample analysis. Among the significant results from the full sample analysis, we find consistent signs of the coefficients in one sub-sample, but most of the time the relationship is statistically insignificant.

\section{Conclusion}

The importance of interest rate movements to the broad equity market and, specifically, listed real estate has been placed into sharp focus since 2007. Not only did the credit markets play a central role in the crisis, but the contribution made by monetary and credit policies over the course of the last cycle has been more astutely considered in recent times. This study considers the exposure and sensitivity of the European listed real estate sector. This allows a comprehensive examination of the issues at hand. Throughout the analysis a number of issues do, however, come to light.

Firstly, in each of the markets bar Switzerland there was evidence of a significant sensitivity at a market level using the baseline GARCH models. This is not only true when the sensitivity with respect to returns is considered. When the 
relationships in the second moment (volatility) are examined, only Belgium and Switzerland fail to provide at least one significant result. The results do, however, reveal variation across the different markets in terms of whether short- or longterm rates are more influential, an impact that is not necessarily consistent across the impact on returns and risk. Furthermore, in relation to much of the broader existing literature there is substantial evidence of temporal variation in the findings. Few markets observe consistent sensitivity, in either returns or volatility, across the entire sample period and the two sub-samples. However, it is important to highlight that the time-variation significance does not necessarily focus upon the later period surrounding the financial crisis. The additional specification which considers the full-range of the yield curve finds broadly similar results.

Given the structure of the European sector, and specifically, the presence of the Euro and the single monetary policy, it is important to note that there is no discernible difference in the findings depending on whether a country is a member of the Eurozone or not. It is of interest that the two markets with some of the weaker findings are Belgium and Switzerland. Belgium is inside the Eurozone; and thus, has no direct control on monetary policy. In contrast, Switzerland is outside both the EU and Eurozone; and therefore, operates an independent monetary policy. In contrast, the remaining five markets are a mix of internal and external to the single currency, and produce generally stronger results. This therefore provides some degree of support for the premise that irrespective of whether monetary policy is set domestically or across the single currency, public real estate firms can be highly sensitive. One issue that this paper has not examined is the degree to which interest rates and monetary policy impact other markets. Both Xu and Yang (2011) and Chang et al. (2013) consider the role of the U.S. monetary policy on overseas assets. The European context, especially due to the presence of the Eurozone, would provide an interesting laboratory to delve further into this issue.

\section{References}

Akimov, A., S. Stevenson, and M. Zagonov (2015). Public Real Estate and the Term Structure of Interest Rates: A Cross-Country Study. Journal of Real Estate Finance and Economics 51(4), 503-540.

Allen, M. T., J. Madura, and T. M. Springer (2000). REIT Characteristics and the Sensitivity of REIT Returns. Journal of Real Estate Finance and Economics 21(2), $141-152$.

Bernanke, B. S. and A. S. Blinder (1992). The federal funds rate and the channels of monetary transmission. American Economic Review 82(4), 901-921. 
Bernanke, B. S. and M. Gertler (1995, nov). Inside the Black Box: The Credit Channel of Monetary Policy Transmission. Journal of Economic Perspectives 9(4), 27-48.

Bernanke, B. S. and K. N. Kuttner (2005). What Explains the Stock Market's Reaction to Federal Reserve Policy? Journal of Finance 60(3), 1221-1257.

Bollerslev, T. and J. M. Wooldridge (1992). Quasi-maximum likelihood estimation and inference in dynamic models with time-varying covariances. Econometric Reviews 11(2), 143-172.

Bredin, D., G. O'Reilly, and S. Stevenson (2007). Monetary shocks and REIT returns. Journal of Real Estate Finance and Economics 35(3), 315-331.

Bredin, D., G. O'Reilly, and S. Stevenson (2011). Monetary policy transmission and real estate investment trusts. International Journal of Finance 83 Economics 16(1), 92-102.

Chang, K. L. (2011). The nonlinear effects of expected and unexpected components of monetary policy on the dynamics of REIT returns. Economic Modelling 28(3), 911-920.

Chang, K. L., N. K. Chen, and C. K. Y. Leung (2011). Monetary Policy, Term Structure and Asset Return: Comparing REIT, Housing and Stock. Journal of Real Estate Finance and Economics 43(1), 221-257.

Chang, K. L., N. K. Chen, and C. K. Y. Leung (2013). In the Shadow of the United States: The International Transmission Effect of Asset Returns. Pacific Economic Review 18(1), 1-40.

Chen, K. and D. Tzang (1988). Interest-Rate Sensitivity of Real Estate Investment Trusts. Journal of Real Estate Research 3(3), 13-22.

Devaney, M. (2001). Time varying risk premia for real estate investment trusts: A GARCH-M model. Quarterly Review of Economics and Finance 41(3), 335-346.

Diebold, F. X. and C. Li (2006). Forecasting the term structure of government bond yields. Journal of Econometrics 130(2), 337-364.

Diebold, F. X., M. Piazzesi, and G. D. Rudebusch (2005). Modeling bond yields in finance and macroeconomics. American Economic Review 95(2), 415-420.

Elyasiani, E. and I. Mansur (1998). Sensitivity of the bank stock returns distribution to changes in the level and volatility of interest rate: A GARCH-M model. Journal of Banking and Finance 22(5), 535-563.

Fabozzi, F. J., L. Martellini, and P. Priaulet (2005). Predictability in the Shape of the Term Structure of Interest Rates. Journal of Fixed Income 15(1), 40-53.

He, L. T., J. R. Webb, and F. C. N. Myer (2003). Interest Rate Sensitivities of REIT Returns. International Real Estate Review 6(1), 1-21.

Lee, C. L., S. Stevenson, and M.-L. Lee (2014). Futures Trading, Spot Price Volatility and Market Efficiency: Evidence from European Real Estate Securities Futures. The Journal of Real Estate Finance and Economics 48(2), 299-322.

Lee, S. and S. Stevenson (2005). The case for REITs in the mixed-asset portfolio in the short and long run. Journal of Real Estate Portfolio Management 11(1), 55-80.

Liang, Y., W. Mclntosh, and J. R. Webb (1995). Intertemporal Changes in the Riskiness of REITs. Journal of Real Estate Research 10(4), 427-444.

Ling, D. C. and A. Naranjo (1997). Economic Risk Factors and Commercial Real Estate Returns. Journal of Real Estate Finance and Economics 14(3), 283-307. 
Litterman, R. B. and J. Scheinkman (1991). Common Factors Affecting Bond Returns. Journal of Fixed Income 1(1), 54-61.

Lizieri, C. ., S. . Satchell, E. . Worzala, and R. Dacco (1998). Real interest regimes and real estate performance: A comparison of U.K. and U.S. markets. Journal of Real Estate Research 16(3), 339-355.

Lizieri, C. and S. Satchell (1997). Property company performance and real interest rates: A regime-switching approach. Journal of Property Research 14(2), 85-97.

Mishkin, F. (1996). The channels of monetary transmission: lessons for monetary policy. NBER Working Paper Series 5464, 1-29.

Nelson, C. R. and A. F. Siegel (1987). Parsimonious Modeling of Yield Curves. Journal of Business 60(4), 473-489.

Plazzi, A., W. Torous, and R. Valkanov (2008). The cross-sectional dispersion of commercial real estate returns and rent growth: Time variation and economic fluctuations. Real Estate Economics 36 (3), 403-439.

Reinhart, V. and T. Simin (1997). The market reaction to federal reserve policy action from 1989 to 1992. Journal of Economics and Business 49(2), 149-168.

Stevenson, S., P. J. Wilson, and R. Zurbruegg (2007). Assessing the Time-Varying Interest Rate Sensitivity of Real Estate Securities. European Journal of Finance 13(8), 705-715.

Swanson, Z., J. Theis, and K. M. Casey (2002). REIT risk premium sensitivity and interest rates. Journal of Real Estate Finance and Economics 24 (3), 319-330.

Xu, P. and J. Yang (2011). U.S. Monetary Policy Surprises and International Securitized Real Estate Markets. Journal of Real Estate Finance and Economics 43(4), 459-490. 
Table 1. Summary statistics.

\begin{tabular}{lrrrrrrr}
\hline & Belgium & France & Germany & Netherlands & Sweden & Switzerland & UK \\
\hline Mean & 0.0011 & 0.0335 & -0.0098 & 0.0047 & 0.0390 & 0.0272 & 0.0104 \\
Minimum & -7.7652 & -8.0961 & -21.5008 & -7.2893 & -10.0383 & -6.9077 & -10.0335 \\
Maximum & 10.4404 & 8.3269 & 13.7813 & 7.6404 & 12.1139 & 7.7447 & 9.3434 \\
Standard Deviation & 0.9664 & 1.2215 & 1.6510 & 1.1456 & 1.4056 & 0.9189 & 1.3028 \\
Skewness & 0.0795 & -0.0667 & -0.6111 & -0.3485 & -0.0329 & -0.1466 & -0.2088 \\
Kurtosis & 8.9153 & 5.5336 & 14.1852 & 6.9801 & 6.3190 & 6.7393 & 7.0758 \\
\hline
\end{tabular}

Note. Table 1 reports summary statistics for the seven listed real estate markets in local currency terms. 
Table 2. Baseline GARCH-M model.

\begin{tabular}{|c|c|c|c|c|c|c|c|c|c|}
\hline & \multicolumn{3}{|c|}{ 1995-2013 } & \multicolumn{3}{|c|}{ 1995-2003 } & \multicolumn{3}{|c|}{ 2004-2013 } \\
\hline & $3 \mathrm{M}$ & $10 \mathrm{Y}$ & Term & $3 \mathrm{M}$ & $10 \mathrm{Y}$ & Term & $3 \mathrm{M}$ & $10 \mathrm{Y}$ & Term \\
\hline \multicolumn{10}{|c|}{ Panel A: Belgium } \\
\hline \multicolumn{10}{|c|}{ Mean Equation } \\
\hline Garch & $\begin{array}{c}0.012 \\
(0.028)\end{array}$ & $\begin{array}{c}0.013 \\
(0.028)\end{array}$ & $\begin{array}{c}0.014 \\
(0.028)\end{array}$ & $\begin{array}{c}0.019 \\
(0.057)\end{array}$ & $\begin{array}{c}0.021 \\
(0.060)\end{array}$ & $\begin{array}{c}0.028 \\
(0.059)\end{array}$ & $\begin{array}{c}0.012 \\
(0.038)\end{array}$ & $\begin{array}{c}0.010 \\
(0.037)\end{array}$ & $\begin{array}{c}0.011 \\
(0.036)\end{array}$ \\
\hline Const & $\begin{array}{c}-0.001 \\
(0.018)\end{array}$ & $\begin{array}{c}-0.002 \\
(0.018)\end{array}$ & $\begin{array}{c}-0.003 \\
(0.018)\end{array}$ & $\begin{array}{c}0.001 \\
(0.028)\end{array}$ & $\begin{array}{c}-0.001 \\
(0.029)\end{array}$ & $\begin{array}{c}-0.004 \\
(0.029)\end{array}$ & $\begin{array}{c}-0.010 \\
(0.025)\end{array}$ & $\begin{array}{c}-0.009 \\
(0.025)\end{array}$ & $\begin{array}{c}-0.010 \\
(0.025)\end{array}$ \\
\hline Market & $\begin{array}{l}0.198^{* * *} \\
(0.011)\end{array}$ & $\begin{array}{l}0.200^{* * *} \\
(0.011)\end{array}$ & $\begin{array}{l}0.199^{* * *} \\
(0.011)\end{array}$ & $\begin{array}{l}0.046^{* * *} \\
(0.011)\end{array}$ & $\begin{array}{l}0.048^{* * *} \\
(0.011)\end{array}$ & $\begin{array}{l}0.047^{* * *} \\
(0.011)\end{array}$ & $\begin{array}{l}0.417^{* * *} \\
(0.018)\end{array}$ & $\begin{array}{l}0.417^{* * *} \\
(0.018)\end{array}$ & $\begin{array}{l}0.416^{* * *} \\
(0.018)\end{array}$ \\
\hline Int.Rate & $\begin{array}{c}0.074 \\
(0.333)\end{array}$ & $\begin{array}{c}-0.591^{* *} \\
(0.266)\end{array}$ & $\begin{array}{c}-0.515^{* *} \\
(0.231)\end{array}$ & $\begin{array}{c}0.255 \\
(0.360)\end{array}$ & $\begin{array}{c}-0.346 \\
(0.308)\end{array}$ & $\begin{array}{c}-0.405 \\
(0.281)\end{array}$ & $\begin{array}{c}-0.155 \\
(0.570)\end{array}$ & $\begin{array}{c}-0.672^{*} \\
(0.378)\end{array}$ & $\begin{array}{c}-0.497 \\
(0.329)\end{array}$ \\
\hline \multicolumn{10}{|c|}{ Variance Equation } \\
\hline Const & $\begin{array}{l}0.011^{* * *} \\
(0.003)\end{array}$ & $\begin{array}{l}0.011 * * * \\
(0.004)\end{array}$ & $\begin{array}{l}0.011 \text { *** } \\
(0.003)\end{array}$ & $\begin{array}{l}0.028^{* * *} \\
(0.010)\end{array}$ & $\begin{array}{l}0.032^{* *} \\
(0.015)\end{array}$ & $\begin{array}{l}0.026^{* *} \\
(0.011)\end{array}$ & $\begin{array}{l}0.012^{* *} \\
(0.006)\end{array}$ & $\begin{array}{l}0.013 * * \\
(0.006)\end{array}$ & $\begin{array}{l}0.013 * * \\
(0.006)\end{array}$ \\
\hline Arch & $\begin{array}{l}0.073^{* * *} \\
(0.011)\end{array}$ & $\begin{array}{l}0.070^{* * *} \\
(0.011)\end{array}$ & $\begin{array}{l}0.074^{* * *} \\
(0.011)\end{array}$ & $\begin{array}{l}0.105^{* * *} \\
(0.022)\end{array}$ & $\begin{array}{l}0.094^{* * *} \\
(0.021)\end{array}$ & $\begin{array}{l}0.103^{* * *} \\
(0.022)\end{array}$ & $\begin{array}{l}0.077^{* * *} \\
(0.018)\end{array}$ & $\begin{array}{l}0.077^{* * *} \\
(0.018)\end{array}$ & $\begin{array}{l}0.079^{* * *} \\
(0.018)\end{array}$ \\
\hline Garch & $\begin{array}{l}0.907^{* * *} \\
(0.014)\end{array}$ & $\begin{array}{l}0.912^{* * *} \\
(0.013)\end{array}$ & $\begin{array}{l}0.906^{* * *} \\
(0.014)\end{array}$ & $\begin{array}{l}0.847^{* * *} \\
(0.033)\end{array}$ & $\begin{array}{l}0.864^{* * *} \\
(0.033)\end{array}$ & $\begin{array}{l}0.851^{* * *} \\
(0.033)\end{array}$ & $\begin{array}{l}0.875^{* * *} \\
(0.033)\end{array}$ & $\begin{array}{l}0.875^{* * *} \\
(0.033)\end{array}$ & $\begin{array}{l}0.872^{* * *} \\
(0.034)\end{array}$ \\
\hline MarketVol. & $\begin{array}{c}0.002 \\
(0.002)\end{array}$ & $\begin{array}{c}0.002 \\
(0.002)\end{array}$ & $\begin{array}{c}0.002 \\
(0.002)\end{array}$ & $\begin{array}{l}-0.002^{* *} \\
(0.001)\end{array}$ & $\begin{array}{l}-0.002^{* * *} \\
(0.001)\end{array}$ & $\begin{array}{c}-0.002^{* *} \\
(0.001)\end{array}$ & $\begin{array}{l}0.018^{* *} \\
(0.009)\end{array}$ & $\begin{array}{l}0.019 * * \\
(0.009)\end{array}$ & $\begin{array}{l}0.018^{* *} \\
(0.009)\end{array}$ \\
\hline Int.RateVol. & $\begin{array}{c}0.698 \\
(0.459)\end{array}$ & $\begin{array}{c}-0.417 \\
(1.339)\end{array}$ & $\begin{array}{c}0.860 \\
(0.874)\end{array}$ & $\begin{array}{c}1.577 \\
(1.208)\end{array}$ & $\begin{array}{c}-2.618 \\
(4.254)\end{array}$ & $\begin{array}{c}1.552 \\
(1.865)\end{array}$ & $\begin{array}{c}0.202 \\
(0.792)\end{array}$ & $\begin{array}{c}-0.994 \\
(1.952)\end{array}$ & $\begin{array}{c}0.417 \\
(1.501)\end{array}$ \\
\hline \multicolumn{10}{|c|}{ Panel B: France } \\
\hline \multicolumn{10}{|c|}{ Mean Equation } \\
\hline Garch & $\begin{array}{c}0.001 \\
(0.022)\end{array}$ & $\begin{array}{c}0.004 \\
(0.022)\end{array}$ & $\begin{array}{c}0.001 \\
(0.022)\end{array}$ & $\begin{array}{c}0.003 \\
(0.066)\end{array}$ & $\begin{array}{c}0.004 \\
(0.068)\end{array}$ & $\begin{array}{c}-0.001 \\
(0.065)\end{array}$ & $\begin{array}{c}-0.040 \\
(0.036)\end{array}$ & $\begin{array}{c}-0.042 \\
(0.037)\end{array}$ & $\begin{array}{c}-0.045 \\
(0.035)\end{array}$ \\
\hline Const & $\begin{array}{l}0.042^{* *} \\
(0.019)\end{array}$ & $\begin{array}{l}0.040^{* *} \\
(0.019)\end{array}$ & $\begin{array}{l}0.043^{* *} \\
(0.019)\end{array}$ & $\begin{array}{c}0.022 \\
(0.031)\end{array}$ & $\begin{array}{c}0.021 \\
(0.032)\end{array}$ & $\begin{array}{c}0.025 \\
(0.031)\end{array}$ & $\begin{array}{l}0.083^{* *} \\
(0.036)\end{array}$ & $\begin{array}{l}0.091^{* *} \\
(0.037)\end{array}$ & $\begin{array}{l}0.088^{* *} \\
(0.035)\end{array}$ \\
\hline Market & $\begin{array}{l}0.282^{* * *} \\
(0.011)\end{array}$ & $\begin{array}{l}0.281^{* * *} \\
(0.011)\end{array}$ & $\begin{array}{l}0.282^{* * *} \\
(0.011)\end{array}$ & $\begin{array}{l}0.125^{* * *} \\
(0.012)\end{array}$ & $\begin{array}{l}0.124^{* * *} \\
(0.012)\end{array}$ & $\begin{array}{l}0.125^{* * *} \\
(0.012)\end{array}$ & $\begin{array}{l}0.703 \text { *** } \\
(0.015)\end{array}$ & $\begin{array}{l}0.690 * * * \\
(0.016)\end{array}$ & $\begin{array}{l}0.702^{* * *} \\
(0.015)\end{array}$ \\
\hline Int.Rate & $\begin{array}{c}-0.272 \\
(0.265)\end{array}$ & $\begin{array}{c}-0.017 \\
(0.256)\end{array}$ & $\begin{array}{c}0.201 \\
(0.223)\end{array}$ & $\begin{array}{c}-0.439^{*} \\
(0.254)\end{array}$ & $\begin{array}{c}-0.180 \\
(0.275)\end{array}$ & $\begin{array}{c}0.189 \\
(0.212)\end{array}$ & $\begin{array}{c}0.495 \\
(0.467)\end{array}$ & $\begin{array}{c}0.558 \\
(0.471)\end{array}$ & $\begin{array}{c}-0.044 \\
(0.349)\end{array}$ \\
\hline \multicolumn{10}{|c|}{ Variance Equation } \\
\hline Const & $\begin{array}{l}0.013^{* * *} \\
(0.004)\end{array}$ & $\begin{array}{l}0.018^{* * *} \\
(0.005)\end{array}$ & $\begin{array}{l}0.013^{* * *} \\
(0.004)\end{array}$ & $\begin{array}{l}0.144^{* * *} \\
(0.047)\end{array}$ & $\begin{array}{l}0.108^{* *} \\
(0.051)\end{array}$ & $\begin{array}{l}0.124^{* * *} \\
(0.047)\end{array}$ & $\begin{array}{l}0.012^{* * *} \\
(0.004)\end{array}$ & $\begin{array}{l}0.036^{* * *} \\
(0.013)\end{array}$ & $\begin{array}{l}0.010^{* *} \\
(0.005)\end{array}$ \\
\hline Arch & $\begin{array}{l}0.076^{* * *} \\
(0.010)\end{array}$ & $\begin{array}{l}0.074^{* * *} \\
(0.010)\end{array}$ & $\begin{array}{l}0.076^{* * *} \\
(0.010)\end{array}$ & $\begin{array}{l}0.165^{* * *} \\
(0.051)\end{array}$ & $\begin{array}{l}0.155^{* * *} \\
(0.050)\end{array}$ & $\begin{array}{l}0.160 * * * \\
(0.050)\end{array}$ & $\begin{array}{l}0.044^{* * *} \\
(0.009)\end{array}$ & $\begin{array}{l}0.095^{* * *} \\
(0.017)\end{array}$ & $\begin{array}{l}0.049^{* * *} \\
(0.010)\end{array}$ \\
\hline Garch & $\begin{array}{l}0.907^{* * *} \\
(0.011)\end{array}$ & $\begin{array}{l}0.909 * * * \\
(0.011)\end{array}$ & $\begin{array}{l}0.906^{* * *} \\
(0.011)\end{array}$ & $\begin{array}{c}0.117 \\
(0.126)\end{array}$ & $\begin{array}{c}0.169 \\
(0.134)\end{array}$ & $\begin{array}{c}0.123 \\
(0.130)\end{array}$ & $\begin{array}{l}0.945^{* * *} \\
(0.011)\end{array}$ & $\begin{array}{l}0.859^{* * *} \\
(0.026)\end{array}$ & $\begin{array}{l}0.937^{* * *} \\
(0.012)\end{array}$ \\
\hline MarketVol. & $\begin{array}{c}0.003 \\
(0.003)\end{array}$ & $\begin{array}{c}0.003 \\
(0.003)\end{array}$ & $\begin{array}{c}0.003 \\
(0.003)\end{array}$ & $\begin{array}{l}0.096^{* *} \\
(0.039)\end{array}$ & $\begin{array}{l}0.087^{* *} \\
(0.038)\end{array}$ & $\begin{array}{l}0.097 * * \\
(0.039)\end{array}$ & $\begin{array}{c}-0.002 \\
(0.002)\end{array}$ & $\begin{array}{c}0.008 \\
(0.006)\end{array}$ & $\begin{array}{c}-0.003 \\
(0.002)\end{array}$ \\
\hline Int.RateVol. & $\begin{array}{c}0.070 \\
(0.168)\end{array}$ & $\begin{array}{c}-3.183^{*} \\
(1.678)\end{array}$ & $\begin{array}{c}0.142 \\
(0.330)\end{array}$ & $\begin{array}{l}1.550^{* *} \\
(0.745)\end{array}$ & $\begin{array}{c}17.314 \\
(14.515)\end{array}$ & $\begin{array}{l}5.510^{* *} \\
(2.386)\end{array}$ & $\begin{array}{c}2.305^{*} \\
(1.223)\end{array}$ & $\begin{array}{c}1.171 \\
(5.381)\end{array}$ & $\begin{array}{c}3.554^{* *} \\
(1.712)\end{array}$ \\
\hline \multicolumn{10}{|c|}{ Panel C: Germany } \\
\hline \multicolumn{10}{|c|}{ Mean Equation } \\
\hline Garch & $\begin{array}{c}-0.006 \\
(0.012)\end{array}$ & $\begin{array}{c}-0.002 \\
(0.011)\end{array}$ & $\begin{array}{c}-0.001 \\
(0.012)\end{array}$ & $\begin{array}{c}0.008 \\
(0.016)\end{array}$ & $\begin{array}{c}0.003 \\
(0.013)\end{array}$ & $\begin{array}{c}0.015 \\
(0.018)\end{array}$ & $\begin{array}{c}-0.019 \\
(0.022)\end{array}$ & $\begin{array}{c}-0.011 \\
(0.022)\end{array}$ & $\begin{array}{c}-0.012 \\
(0.022)\end{array}$ \\
\hline Const & $\begin{array}{c}0.020 \\
(0.020)\end{array}$ & $\begin{array}{c}0.011 \\
(0.020)\end{array}$ & $\begin{array}{c}0.008 \\
(0.022)\end{array}$ & $\begin{array}{c}-0.014 \\
(0.036)\end{array}$ & $\begin{array}{c}0.004 \\
(0.026)\end{array}$ & $\begin{array}{c}-0.038 \\
(0.045)\end{array}$ & $\begin{array}{c}0.029 \\
(0.028)\end{array}$ & $\begin{array}{c}0.019 \\
(0.028)\end{array}$ & $\begin{array}{c}0.020 \\
(0.028)\end{array}$ \\
\hline Market & $\begin{array}{l}0.368^{* * *} \\
(0.014)\end{array}$ & $\begin{array}{l}0.369^{* * *} \\
(0.017)\end{array}$ & $\begin{array}{l}0.375^{* * *} \\
(0.017)\end{array}$ & $\begin{array}{l}0.173^{* * *} \\
(0.020)\end{array}$ & $\begin{array}{l}0.160^{* * *} \\
(0.021)\end{array}$ & $\begin{array}{l}0.171^{* * *} \\
(0.022)\end{array}$ & $\begin{array}{l}0.556^{* * *} \\
(0.018)\end{array}$ & $\begin{array}{l}0.554^{* * *} \\
(0.018)\end{array}$ & $\begin{array}{l}0.554^{* * *} \\
(0.018)\end{array}$ \\
\hline Int.Rate & $\begin{array}{c}-0.403 \\
(1.039)\end{array}$ & $\begin{array}{c}0.486 \\
(0.422)\end{array}$ & $\begin{array}{c}0.443 \\
(0.465)\end{array}$ & $\begin{array}{c}0.313 \\
(1.007)\end{array}$ & $\begin{array}{c}0.926 \\
(0.601)\end{array}$ & $\begin{array}{c}0.976 \\
(0.686)\end{array}$ & $\begin{array}{c}-4.768^{* *} \\
(2.068)\end{array}$ & $\begin{array}{c}0.318 \\
(0.484)\end{array}$ & $\begin{array}{c}0.536 \\
(0.483)\end{array}$ \\
\hline \multicolumn{10}{|c|}{ Variance Equation } \\
\hline Const & $\begin{array}{c}0.009^{*} \\
(0.005)\end{array}$ & $\begin{array}{c}-0.003 \\
(0.017)\end{array}$ & $\begin{array}{c}0.008 \\
(0.008)\end{array}$ & $\begin{array}{c}0.002 \\
(0.025)\end{array}$ & $\begin{array}{c}-0.037 \\
(0.037)\end{array}$ & $\begin{array}{c}0.058^{*} \\
(0.031)\end{array}$ & $\begin{array}{l}0.024^{* * *} \\
(0.008)\end{array}$ & $\begin{array}{c}0.018 \\
(0.011)\end{array}$ & $\begin{array}{c}0.016 \\
(0.010)\end{array}$ \\
\hline Arch & $\begin{array}{l}0.074^{* * *} \\
(0.012)\end{array}$ & $\begin{array}{l}0.093^{* * *} \\
(0.014)\end{array}$ & $\begin{array}{l}0.087^{* * * *} \\
(0.013)\end{array}$ & $\begin{array}{l}0.066^{* * *} \\
(0.019)\end{array}$ & $\begin{array}{l}0.101^{* * *} \\
(0.026)\end{array}$ & $\begin{array}{l}0.089 * * * \\
(0.023)\end{array}$ & $\begin{array}{l}0.094^{* * *} \\
(0.015)\end{array}$ & $\begin{array}{l}0.091^{* * *} \\
(0.014)\end{array}$ & $\begin{array}{l}0.091^{* * *} \\
(0.014)\end{array}$ \\
\hline Garch & $\begin{array}{l}0.924^{* * *} \\
(0.012)\end{array}$ & $\begin{array}{l}0.902^{* * *} \\
(0.017)\end{array}$ & $\begin{array}{l}0.909^{* * *} \\
(0.015)\end{array}$ & $\begin{array}{l}0.932^{* * *} \\
(0.015)\end{array}$ & $\begin{array}{l}0.899 * * * \\
(0.026)\end{array}$ & $\begin{array}{l}0.902^{* * *} \\
(0.028)\end{array}$ & $\begin{array}{l}0.884^{* * *} \\
(0.017)\end{array}$ & $\begin{array}{l}0.893^{* * *} \\
(0.015)\end{array}$ & $\begin{array}{l}0.893^{* * *} \\
(0.015)\end{array}$ \\
\hline
\end{tabular}


Table 2. Continued.

\begin{tabular}{|c|c|c|c|c|c|c|c|c|c|}
\hline & \multicolumn{3}{|c|}{$1995-2013$} & \multicolumn{3}{|c|}{$1995-2003$} & \multicolumn{3}{|c|}{$2004-2013$} \\
\hline & $3 \mathrm{M}$ & $10 Y$ & Term & $3 \mathrm{M}$ & $10 Y$ & Term & $3 \mathrm{M}$ & $10 Y$ & Term \\
\hline MarketVol. & $\begin{array}{c}0.001 \\
(0.005)\end{array}$ & $\begin{array}{c}0.004 \\
(0.010)\end{array}$ & $\begin{array}{c}0.003 \\
(0.009)\end{array}$ & $\begin{array}{c}0.002 \\
(0.011)\end{array}$ & $\begin{array}{c}0.011 \\
(0.019)\end{array}$ & $\begin{array}{c}0.008 \\
(0.020)\end{array}$ & $\begin{array}{c}0.001 \\
(0.005)\end{array}$ & $\begin{array}{c}-0.002 \\
(0.006)\end{array}$ & $\begin{array}{c}-0.004 \\
(0.006)\end{array}$ \\
\hline Int.RateVol. & $\begin{array}{l}12.190 \\
(7.522)\end{array}$ & $\begin{array}{c}14.493 \\
(16.761)\end{array}$ & $\begin{array}{c}6.125 \\
(7.465)\end{array}$ & $\begin{array}{c}27.414 \\
(29.417)\end{array}$ & $\begin{array}{c}31.640 \\
(27.139)\end{array}$ & $\begin{array}{c}-9.909 \\
(9.033)\end{array}$ & $\begin{array}{c}50.858^{*} \\
(30.660)\end{array}$ & $\begin{array}{c}5.270 \\
(8.412)\end{array}$ & $\begin{array}{c}8.849 \\
(7.753)\end{array}$ \\
\hline \multicolumn{10}{|c|}{ Panel D: Netherlands } \\
\hline \multicolumn{10}{|c|}{ Mean Equation } \\
\hline Garch & $\begin{array}{c}0.005 \\
(0.020)\end{array}$ & $\begin{array}{c}0.011 \\
(0.020)\end{array}$ & $\begin{array}{c}0.006 \\
(0.020)\end{array}$ & $\begin{array}{c}0.073 \\
(0.058)\end{array}$ & $\begin{array}{c}0.138^{*} \\
(0.082)\end{array}$ & $\begin{array}{c}0.119 \\
(0.080)\end{array}$ & $\begin{array}{c}-0.023 \\
(0.028)\end{array}$ & $\begin{array}{c}-0.027 \\
(0.029)\end{array}$ & $\begin{array}{c}-0.030 \\
(0.029)\end{array}$ \\
\hline Const & $\begin{array}{c}0.018 \\
(0.015)\end{array}$ & $\begin{array}{c}0.012 \\
(0.015)\end{array}$ & $\begin{array}{c}0.016 \\
(0.015)\end{array}$ & $\begin{array}{c}-0.021 \\
(0.015)\end{array}$ & $\begin{array}{c}-0.044^{*} \\
(0.025)\end{array}$ & $\begin{array}{c}-0.038 \\
(0.024)\end{array}$ & $\begin{array}{c}0.032 \\
(0.027)\end{array}$ & $\begin{array}{c}0.037 \\
(0.028)\end{array}$ & $\begin{array}{c}0.039 \\
(0.028)\end{array}$ \\
\hline Market & $\begin{array}{l}0.193^{* * *} \\
(0.008)\end{array}$ & $\begin{array}{l}0.192^{* * *} \\
(0.009)\end{array}$ & $\begin{array}{l}0.193^{* * *} \\
(0.008)\end{array}$ & $\begin{array}{l}0.104^{* * *} \\
(0.009)\end{array}$ & $\begin{array}{l}0.104^{* * *} \\
(0.009)\end{array}$ & $\begin{array}{l}0.104^{* * *} \\
(0.009)\end{array}$ & $\begin{array}{l}0.687^{* * *} \\
(0.018)\end{array}$ & $\begin{array}{l}0.685^{* * *} \\
(0.018)\end{array}$ & $\begin{array}{l}0.685^{* * *} \\
(0.018)\end{array}$ \\
\hline Int.Rate & $\begin{array}{c}0.083 \\
(0.361)\end{array}$ & $\begin{array}{c}0.200 \\
(0.251)\end{array}$ & $\begin{array}{c}0.106 \\
(0.223)\end{array}$ & $\begin{array}{c}0.177 \\
(0.356)\end{array}$ & $\begin{array}{c}0.097 \\
(0.260)\end{array}$ & $\begin{array}{c}-0.013 \\
(0.224)\end{array}$ & $\begin{array}{c}0.267 \\
(0.510)\end{array}$ & $\begin{array}{l}1.005^{* *} \\
(0.488)\end{array}$ & $\begin{array}{c}0.588 \\
(0.376)\end{array}$ \\
\hline \multicolumn{10}{|c|}{ Variance Equation } \\
\hline Const & $\begin{array}{l}0.011^{* * *} \\
(0.004)\end{array}$ & $\begin{array}{l}0.015^{* *} \\
(0.006)\end{array}$ & $\begin{array}{l}0.011^{* * *} \\
(0.004)\end{array}$ & $\begin{array}{l}0.135^{* * *} \\
(0.036)\end{array}$ & $\begin{array}{l}0.105^{* *} \\
(0.050)\end{array}$ & $\begin{array}{l}0.116^{* * *} \\
(0.038)\end{array}$ & $\begin{array}{l}0.032^{* * *} \\
(0.011)\end{array}$ & $\begin{array}{c}0.013 \\
(0.014)\end{array}$ & $\begin{array}{c}0.017^{*} \\
(0.010)\end{array}$ \\
\hline Arch & $\begin{array}{l}0.076^{* * *} \\
(0.009)\end{array}$ & $\begin{array}{l}0.077^{* * *} \\
(0.009)\end{array}$ & $\begin{array}{l}0.072^{* * *} \\
(0.009)\end{array}$ & $\begin{array}{l}0.201^{* * *} \\
(0.042)\end{array}$ & $\begin{array}{l}0.191^{* * *} \\
(0.042)\end{array}$ & $\begin{array}{l}0.190^{* * *} \\
(0.042)\end{array}$ & $\begin{array}{l}0.096^{* * *} \\
(0.020)\end{array}$ & $\begin{array}{l}0.087^{* * *} \\
(0.017)\end{array}$ & $\begin{array}{l}0.096^{* * *} \\
(0.020)\end{array}$ \\
\hline Garch & $\begin{array}{l}0.914^{* * *} \\
(0.010)\end{array}$ & $\begin{array}{l}0.914^{* * *} \\
(0.010)\end{array}$ & $\begin{array}{l}0.918^{* * *} \\
(0.009)\end{array}$ & $\begin{array}{l}0.235^{* *} \\
(0.118)\end{array}$ & $\begin{array}{l}0.337^{* * *} \\
(0.127)\end{array}$ & $\begin{array}{l}0.348^{* * *} \\
(0.128)\end{array}$ & $\begin{array}{l}0.818^{* * * *} \\
(0.044)\end{array}$ & $\begin{array}{l}0.867^{* * *} \\
(0.031)\end{array}$ & $\begin{array}{l}0.821^{* * *} \\
(0.047)\end{array}$ \\
\hline MarketVol. & $\begin{array}{c}-0.001 \\
(0.001)\end{array}$ & $\begin{array}{c}0.000 \\
(0.001)\end{array}$ & $\begin{array}{c}0.000 \\
(0.001)\end{array}$ & $\begin{array}{l}0.020^{* *} \\
(0.008)\end{array}$ & $\begin{array}{l}0.016^{* *} \\
(0.007)\end{array}$ & $\begin{array}{l}0.016^{* *} \\
(0.007)\end{array}$ & $\begin{array}{l}0.029^{* *} \\
(0.014)\end{array}$ & $\begin{array}{l}0.020^{* *} \\
(0.010)\end{array}$ & $\begin{array}{c}0.022^{*} \\
(0.012)\end{array}$ \\
\hline Int.RateVol. & $\begin{array}{l}-0.556^{* * *} \\
(0.187)\end{array}$ & $\begin{array}{c}-3.356 \\
(2.660)\end{array}$ & $\begin{array}{l}-0.761^{* * *} \\
(0.237)\end{array}$ & $\begin{array}{c}-2.260^{* * *} \\
(0.330)\end{array}$ & $\begin{array}{c}3.310 \\
(13.739)\end{array}$ & $\begin{array}{c}-2.791 * * \\
(1.309)\end{array}$ & $\begin{array}{l}11.358^{* *} \\
(4.617)\end{array}$ & $\begin{array}{c}5.470 \\
(11.943)\end{array}$ & $\begin{array}{l}14.725^{* *} \\
(7.389)\end{array}$ \\
\hline \multicolumn{10}{|c|}{ Panel E: Sweden } \\
\hline \multicolumn{10}{|c|}{ Mean Equation } \\
\hline Garch & $\begin{array}{c}0.006 \\
(0.018)\end{array}$ & $\begin{array}{c}0.007 \\
(0.017)\end{array}$ & $\begin{array}{c}0.006 \\
(0.017)\end{array}$ & $\begin{array}{c}0.036 \\
(0.044)\end{array}$ & $\begin{array}{c}0.027 \\
(0.043)\end{array}$ & $\begin{array}{c}0.037 \\
(0.044)\end{array}$ & $\begin{array}{c}0.016 \\
(0.024)\end{array}$ & $\begin{array}{c}0.013 \\
(0.025)\end{array}$ & $\begin{array}{c}0.018 \\
(0.024)\end{array}$ \\
\hline Const & $\begin{array}{c}0.032 \\
(0.020)\end{array}$ & $\begin{array}{c}0.032 \\
(0.019)\end{array}$ & $\begin{array}{c}0.033^{*} \\
(0.020)\end{array}$ & $\begin{array}{c}-0.008 \\
(0.032)\end{array}$ & $\begin{array}{c}-0.004 \\
(0.032)\end{array}$ & $\begin{array}{c}-0.009 \\
(0.032)\end{array}$ & $\begin{array}{c}0.014 \\
(0.032)\end{array}$ & $\begin{array}{c}0.021 \\
(0.032)\end{array}$ & $\begin{array}{c}0.013 \\
(0.032)\end{array}$ \\
\hline Market & $\begin{array}{l}0.362^{* * *} \\
(0.011)\end{array}$ & $\begin{array}{l}0.364^{* * *} \\
(0.011)\end{array}$ & $\begin{array}{l}0.362^{* * *} \\
(0.011)\end{array}$ & $\begin{array}{l}0.236^{* * *} \\
(0.012)\end{array}$ & $\begin{array}{l}0.234^{* * *} \\
(0.012)\end{array}$ & $\begin{array}{l}0.236^{* * *} \\
(0.012)\end{array}$ & $\begin{array}{l}0.693^{* * *} \\
(0.019)\end{array}$ & $\begin{array}{l}0.693^{* * *} \\
(0.019)\end{array}$ & $\begin{array}{l}0.693^{* * *} \\
(0.018)\end{array}$ \\
\hline Int.Rate & $\begin{array}{c}-0.633^{*} \\
(0.330)\end{array}$ & $\begin{array}{c}-0.228 \\
(0.340)\end{array}$ & $\begin{array}{c}0.175 \\
(0.243)\end{array}$ & $\begin{array}{c}-0.375 \\
(0.641)\end{array}$ & $\begin{array}{c}-0.325 \\
(0.337)\end{array}$ & $\begin{array}{c}-0.208 \\
(0.324)\end{array}$ & $\begin{array}{c}-0.660^{*} \\
(0.351)\end{array}$ & $\begin{array}{c}0.772 \\
(0.515)\end{array}$ & $\begin{array}{l}0.714^{* *} \\
(0.299)\end{array}$ \\
\hline \multicolumn{10}{|c|}{ Variance Equation } \\
\hline Const & $\begin{array}{l}0.019 \text { *** } \\
(0.007)\end{array}$ & $\begin{array}{l}0.024^{* * *} \\
(0.006)\end{array}$ & $\begin{array}{l}0.016^{* *} \\
(0.006)\end{array}$ & $\begin{array}{l}0.070^{* *} \\
(0.027)\end{array}$ & $\begin{array}{l}0.047^{* *} \\
(0.022)\end{array}$ & $\begin{array}{c}0.046^{* *} \\
(0.023)\end{array}$ & $\begin{array}{c}0.011^{*} \\
(0.007)\end{array}$ & $\begin{array}{l}0.028^{* *} \\
(0.011)\end{array}$ & $\begin{array}{c}0.011 \\
(0.007)\end{array}$ \\
\hline Arch & $\begin{array}{l}0.095^{* * *} \\
(0.015)\end{array}$ & $\begin{array}{l}0.095^{* * *} \\
(0.015)\end{array}$ & $\begin{array}{l}0.095^{* * *} \\
(0.014)\end{array}$ & $\begin{array}{l}0.186^{* * *} \\
(0.059)\end{array}$ & $\begin{array}{l}0.193^{* * *} \\
(0.057)\end{array}$ & $\begin{array}{l}0.189 * * * \\
(0.054)\end{array}$ & $\begin{array}{l}0.067^{* * *} \\
(0.016)\end{array}$ & $\begin{array}{l}0.064^{* * *} \\
(0.017)\end{array}$ & $\begin{array}{l}0.069 * * * \\
(0.016)\end{array}$ \\
\hline Garch & $\begin{array}{l}0.888^{* * *} \\
(0.017)\end{array}$ & $\begin{array}{l}0.894^{* * *} \\
(0.017)\end{array}$ & $\begin{array}{l}0.890^{* * *} \\
(0.016)\end{array}$ & $\begin{array}{l}0.670^{* * *} \\
(0.080)\end{array}$ & $\begin{array}{l}0.634^{* * *} \\
(0.090)\end{array}$ & $\begin{array}{l}0.655^{* * *} \\
(0.084)\end{array}$ & $\begin{array}{l}0.921^{* * *} * \\
(0.020)\end{array}$ & $\begin{array}{l}0.919 * * * \\
(0.022)\end{array}$ & $\begin{array}{l}0.919^{* * *} \\
(0.020)\end{array}$ \\
\hline MarketVol. & $\begin{array}{c}0.001 \\
(0.002)\end{array}$ & $\begin{array}{c}0.000 \\
(0.002)\end{array}$ & $\begin{array}{c}0.001 \\
(0.002)\end{array}$ & $\begin{array}{c}0.012^{*} \\
(0.006)\end{array}$ & $\begin{array}{l}0.018^{* *} \\
(0.008)\end{array}$ & $\begin{array}{l}0.015^{* *} \\
(0.007)\end{array}$ & $\begin{array}{c}0.004 \\
(0.005)\end{array}$ & $\begin{array}{c}0.010 \\
(0.006)\end{array}$ & $\begin{array}{c}0.004 \\
(0.005)\end{array}$ \\
\hline Int.RateVol. & $\begin{array}{c}1.229 * \\
(0.657)\end{array}$ & $\begin{array}{c}-1.418 \\
(1.539)\end{array}$ & $\begin{array}{c}1.434 \\
(1.139) \\
\end{array}$ & $\begin{array}{c}13.715^{*} \\
(7.512)\end{array}$ & $\begin{array}{c}13.560^{*} \\
(7.039)\end{array}$ & $\begin{array}{l}12.449 \\
(8.285)\end{array}$ & $\begin{array}{c}0.379 \\
(0.447) \\
\end{array}$ & $\begin{array}{c}-10.936^{*} \\
(5.855)\end{array}$ & $\begin{array}{c}0.650 \\
(0.925) \\
\end{array}$ \\
\hline \multicolumn{10}{|c|}{ Panel F: Switzerland } \\
\hline \multicolumn{10}{|c|}{ Mean Equation } \\
\hline Garch & $\begin{array}{c}-0.010 \\
(0.022)\end{array}$ & $\begin{array}{c}-0.008 \\
(0.022)\end{array}$ & $\begin{array}{c}-0.009 \\
(0.022)\end{array}$ & $\begin{array}{c}0.030 \\
(0.027)\end{array}$ & $\begin{array}{c}0.046 \\
(0.031)\end{array}$ & $\begin{array}{c}0.052^{*} \\
(0.031)\end{array}$ & $\begin{array}{c}-0.054 \\
(0.037)\end{array}$ & $\begin{array}{c}-0.056 \\
(0.038)\end{array}$ & $\begin{array}{c}-0.054 \\
(0.037)\end{array}$ \\
\hline Const & $\begin{array}{l}0.036^{* * *} \\
(0.014)\end{array}$ & $\begin{array}{l}0.035^{* *} \\
(0.014)\end{array}$ & $\begin{array}{l}0.035^{* *} \\
(0.014)\end{array}$ & $\begin{array}{c}-0.005 \\
(0.018)\end{array}$ & $\begin{array}{c}-0.011 \\
(0.020)\end{array}$ & $\begin{array}{c}-0.014 \\
(0.020)\end{array}$ & $\begin{array}{l}0.053^{* * *} \\
(0.021)\end{array}$ & $\begin{array}{l}0.055^{* * *} \\
(0.021)\end{array}$ & $\begin{array}{l}0.054^{* * *} \\
(0.021)\end{array}$ \\
\hline Market & $\begin{array}{l}0.126^{* * *} \\
(0.011)\end{array}$ & $\begin{array}{l}0.127^{* * *} \\
(0.011)\end{array}$ & $\begin{array}{l}0.129 * * * \\
(0.011)\end{array}$ & $\begin{array}{l}0.047^{* * *} \\
(0.010)\end{array}$ & $\begin{array}{l}0.048^{* * *} \\
(0.011)\end{array}$ & $\begin{array}{l}0.048^{* * *} \\
(0.011)\end{array}$ & $\begin{array}{l}0.311^{* * *} \\
(0.020)\end{array}$ & $\begin{array}{l}0.312^{* * *} \\
(0.020)\end{array}$ & $\begin{array}{l}0.310^{* * *} \\
(0.020)\end{array}$ \\
\hline Int.Rate & $\begin{array}{c}0.211 \\
(0.238)\end{array}$ & $\begin{array}{c}0.166 \\
(0.318)\end{array}$ & $\begin{array}{c}-0.112 \\
(0.203)\end{array}$ & $\begin{array}{c}0.328 \\
(0.365)\end{array}$ & $\begin{array}{c}-0.293 \\
(0.368)\end{array}$ & $\begin{array}{c}-0.309 \\
(0.283)\end{array}$ & $\begin{array}{c}0.038 \\
(0.234)\end{array}$ & $\begin{array}{c}0.561 \\
(0.525)\end{array}$ & $\begin{array}{c}0.106 \\
(0.223)\end{array}$ \\
\hline
\end{tabular}


Table 2. Continued.

\begin{tabular}{|c|c|c|c|c|c|c|c|c|c|}
\hline & \multicolumn{3}{|c|}{$1995-2013$} & \multicolumn{3}{|c|}{ 1995-2003 } & \multicolumn{3}{|c|}{ 2004-2013 } \\
\hline & $3 \mathrm{M}$ & $10 Y$ & Term & $3 \mathrm{M}$ & $10 Y$ & Term & $3 \mathrm{M}$ & $10 \mathrm{Y}$ & Term \\
\hline \multicolumn{10}{|c|}{ Variance Equation } \\
\hline Const & $\begin{array}{l}0.019 * * * \\
(0.007)\end{array}$ & $\begin{array}{l}0.022^{* *} \\
(0.011)\end{array}$ & $\begin{array}{l}0.019 * * * \\
(0.007)\end{array}$ & $\begin{array}{l}0.012^{* *} \\
(0.006)\end{array}$ & $\begin{array}{c}0.005 \\
(0.003)\end{array}$ & $\begin{array}{c}0.003^{*} \\
(0.002)\end{array}$ & $\begin{array}{l}0.026^{* *} \\
(0.010)\end{array}$ & $\begin{array}{c}0.021 \\
(0.021)\end{array}$ & $\begin{array}{l}0.026^{* *} \\
(0.010)\end{array}$ \\
\hline Arch & $\begin{array}{l}0.126^{* * *} \\
(0.019)\end{array}$ & $\begin{array}{l}0.115^{* * *} \\
(0.019)\end{array}$ & $\begin{array}{l}0.120^{* * *} \\
(0.019)\end{array}$ & $\begin{array}{l}0.149^{* * *} \\
(0.025)\end{array}$ & $\begin{array}{l}0.029^{* * *} \\
(0.010)\end{array}$ & $\begin{array}{l}0.024^{* * *} \\
(0.008)\end{array}$ & $\begin{array}{l}0.151^{* * * *} \\
(0.034)\end{array}$ & $\begin{array}{l}0.153^{* * *} \\
(0.036)\end{array}$ & $\begin{array}{l}0.150^{* * *} \\
(0.034)\end{array}$ \\
\hline Garch & $\begin{array}{l}0.856^{* * *} \\
(0.019)\end{array}$ & $\begin{array}{l}0.871^{* * *} \\
(0.017)\end{array}$ & $\begin{array}{l}0.862^{* * *} \\
(0.018)\end{array}$ & $\begin{array}{l}0.832^{* * *} \\
(0.032)\end{array}$ & $\begin{array}{l}0.968^{* * *} \\
(0.010)\end{array}$ & $\begin{array}{l}0.974^{* * *} \\
(0.008)\end{array}$ & $\begin{array}{l}0.769^{* * *} \\
(0.040)\end{array}$ & $\begin{array}{l}0.757^{* * *} \\
(0.040)\end{array}$ & $\begin{array}{l}0.770^{* * *} \\
(0.041)\end{array}$ \\
\hline MarketVol. & $\begin{array}{c}-0.001 \\
(0.002)\end{array}$ & $\begin{array}{c}0.000 \\
(0.001)\end{array}$ & $\begin{array}{c}-0.001 \\
(0.001)\end{array}$ & $\begin{array}{c}-0.001 \\
(0.001)\end{array}$ & $\begin{array}{c}0.000 \\
(0.000)\end{array}$ & $\begin{array}{c}0.000 \\
(0.000)\end{array}$ & $\begin{array}{l}0.027^{* *} \\
(0.013)\end{array}$ & $\begin{array}{l}0.025^{* *} \\
(0.013)\end{array}$ & $\begin{array}{l}0.027^{* *} \\
(0.013)\end{array}$ \\
\hline Int.RateVol. & $\begin{array}{c}0.394 \\
(0.383)\end{array}$ & $\begin{array}{c}-4.349 \\
(4.988)\end{array}$ & $\begin{array}{c}0.228 \\
(0.318)\end{array}$ & $\begin{array}{c}4.910 \\
(3.168)\end{array}$ & $\begin{array}{c}-1.963 \\
(1.626)\end{array}$ & $\begin{array}{c}-0.489 \\
(0.392)\end{array}$ & $\begin{array}{c}-0.364 \\
(0.262)\end{array}$ & $\begin{array}{c}8.345 \\
(18.250)\end{array}$ & $\begin{array}{c}-0.287 \\
(0.460)\end{array}$ \\
\hline \multicolumn{10}{|c|}{ Panel G: UK } \\
\hline \multicolumn{10}{|c|}{ Mean Equation } \\
\hline Garch & $\begin{array}{c}-0.047^{* *} \\
(0.019)\end{array}$ & $\begin{array}{l}-0.043^{* *} \\
(0.019)\end{array}$ & $\begin{array}{c}-0.044^{* *} \\
(0.019)\end{array}$ & $\begin{array}{l}0.182^{* *} \\
(0.081)\end{array}$ & $\begin{array}{c}-0.058 \\
(0.059)\end{array}$ & $\begin{array}{c}-0.050 \\
(0.059)\end{array}$ & $\begin{array}{c}-0.049^{* *} \\
(0.024)\end{array}$ & $\begin{array}{c}-0.051^{* *} \\
(0.024)\end{array}$ & $\begin{array}{c}-0.045^{*} \\
(0.023)\end{array}$ \\
\hline Const & $\begin{array}{l}0.065^{* * *} \\
(0.016)\end{array}$ & $\begin{array}{l}0.062^{* * *} \\
(0.016)\end{array}$ & $\begin{array}{l}0.063^{* * *} \\
(0.016)\end{array}$ & $\begin{array}{c}-0.164^{* *} \\
(0.078)\end{array}$ & $\begin{array}{c}0.049 \\
(0.031)\end{array}$ & $\begin{array}{c}0.045 \\
(0.031)\end{array}$ & $\begin{array}{l}0.062^{* * *} \\
(0.021)\end{array}$ & $\begin{array}{l}0.063^{* * *} \\
(0.021)\end{array}$ & $\begin{array}{l}0.058^{* * * *} \\
(0.021)\end{array}$ \\
\hline Market & $\begin{array}{l}0.460^{* * *} \\
(0.013)\end{array}$ & $\begin{array}{l}0.460^{* * *} \\
(0.012)\end{array}$ & $\begin{array}{l}0.460^{* * *} \\
(0.013)\end{array}$ & $\begin{array}{l}0.273^{* * *} \\
(0.018)\end{array}$ & $\begin{array}{l}0.259^{* * *} \\
(0.017)\end{array}$ & $\begin{array}{l}0.259^{* * *} \\
(0.017)\end{array}$ & $\begin{array}{l}0.852^{* * *} \\
(0.019)\end{array}$ & $\begin{array}{l}0.847^{* * *} \\
(0.019)\end{array}$ & $\begin{array}{l}0.848^{* * *} \\
(0.019)\end{array}$ \\
\hline Int.Rate & $\begin{array}{c}-0.738^{* *} \\
(0.310)\end{array}$ & $\begin{array}{c}-0.188 \\
(0.236)\end{array}$ & $\begin{array}{c}0.147 \\
(0.196)\end{array}$ & $\begin{array}{c}-0.099 \\
(0.375)\end{array}$ & $\begin{array}{c}-0.410 \\
(0.285)\end{array}$ & $\begin{array}{c}0.095 \\
(0.220)\end{array}$ & $\begin{array}{c}-0.090 \\
(0.855)\end{array}$ & $\begin{array}{c}0.273 \\
(0.363)\end{array}$ & $\begin{array}{c}0.272 \\
(0.357)\end{array}$ \\
\hline \multicolumn{10}{|c|}{ Variance Equation } \\
\hline Const & $\begin{array}{l}0.008^{* * *} \\
(0.003)\end{array}$ & $\begin{array}{l}0.012^{* * *} \\
(0.004)\end{array}$ & $\begin{array}{l}0.009^{* * *} \\
(0.003)\end{array}$ & $\begin{array}{c}0.489 \\
(0.361)\end{array}$ & $\begin{array}{c}0.009 \\
(0.009)\end{array}$ & $\begin{array}{c}0.009 \\
(0.009)\end{array}$ & $\begin{array}{c}0.004^{*} \\
(0.002)\end{array}$ & $\begin{array}{l}0.010^{* * *} \\
(0.003)\end{array}$ & $\begin{array}{l}0.006^{* *} \\
(0.003)\end{array}$ \\
\hline Arch & $\begin{array}{l}0.068^{* * *} \\
(0.008)\end{array}$ & $\begin{array}{l}0.067^{* * *} \\
(0.008)\end{array}$ & $\begin{array}{l}0.069^{* * *} \\
(0.008)\end{array}$ & $\begin{array}{c}0.017 \\
(0.024)\end{array}$ & $\begin{array}{l}0.088^{* * *} \\
(0.020)\end{array}$ & $\begin{array}{l}0.084^{* * *} \\
(0.017)\end{array}$ & $\begin{array}{l}0.041^{* * *} \\
(0.007)\end{array}$ & $\begin{array}{l}0.035^{* * *} \\
(0.006)\end{array}$ & $\begin{array}{l}0.042^{* * *} \\
(0.007)\end{array}$ \\
\hline Garch & $\begin{array}{l}0.921^{* * *} \\
(0.010)\end{array}$ & $\begin{array}{l}0.923^{* * *} \\
(0.010)\end{array}$ & $\begin{array}{l}0.920^{* * *} \\
(0.010)\end{array}$ & $\begin{array}{c}0.531 \\
(0.351)\end{array}$ & $\begin{array}{l}0.865^{* * *} \\
(0.044)\end{array}$ & $\begin{array}{l}0.877^{* * *} \\
(0.032)\end{array}$ & $\begin{array}{l}0.954^{* * *} \\
(0.007)\end{array}$ & $\begin{array}{l}0.959^{* * *} \\
(0.006)\end{array}$ & $\begin{array}{l}0.955^{* * *} \\
(0.006)\end{array}$ \\
\hline MarketVol. & $\begin{array}{c}0.001 \\
(0.002)\end{array}$ & $\begin{array}{c}0.002 \\
(0.002)\end{array}$ & $\begin{array}{c}0.002 \\
(0.002)\end{array}$ & $\begin{array}{c}-0.021 \\
(0.017)\end{array}$ & $\begin{array}{c}0.005 \\
(0.004)\end{array}$ & $\begin{array}{c}0.003 \\
(0.003)\end{array}$ & $\begin{array}{c}0.001 \\
(0.003)\end{array}$ & $\begin{array}{l}0.007^{* *} \\
(0.003)\end{array}$ & $\begin{array}{c}0.004 \\
(0.003)\end{array}$ \\
\hline Int.RateVol. & $\begin{array}{c}0.590 \\
(0.736)\end{array}$ & $\begin{array}{c}-1.378 \\
(1.649)\end{array}$ & $\begin{array}{c}-0.019 \\
(0.790)\end{array}$ & $\begin{array}{l}-5.392^{* * *} \\
(1.198)\end{array}$ & $\begin{array}{c}4.608 \\
(4.141)\end{array}$ & $\begin{array}{c}2.184 \\
(1.586)\end{array}$ & $\begin{array}{c}0.973 \\
(1.028)\end{array}$ & $\begin{array}{l}-4.712^{* * *} \\
(1.461)\end{array}$ & $\begin{array}{c}-1.816^{*} \\
(0.938)\end{array}$ \\
\hline
\end{tabular}


Table 3. GARCH Multifactor model results using the yield curve parameters.

\begin{tabular}{|c|c|c|c|c|c|c|c|c|c|}
\hline & $\mu_{0, i}$ & $\beta_{1, i}$ & $\beta_{2, i}$ & $\beta_{2, i}$ & $\beta_{4, i}$ & $a_{1, i}$ & $b_{1, i}$ & Adj. $R^{2}$ & Wald \\
\hline \multicolumn{10}{|l|}{ Belgium } \\
\hline 1995-2013 & $\begin{array}{c}0.006 \\
(0.01)\end{array}$ & $\begin{array}{c}-0.296 \\
(0.24)\end{array}$ & $\begin{array}{c}-0.299 \\
(0.20)\end{array}$ & $\begin{array}{l}-0.256^{* * *} \\
(0.08)\end{array}$ & $\begin{array}{l}0.193^{* * *} \\
(0.01)\end{array}$ & $\begin{array}{l}0.072^{* * *} \\
(0.01)\end{array}$ & $\begin{array}{l}0.913^{* * *} \\
(0.01)\end{array}$ & 0.12 & $\begin{array}{l}12.00^{* * *} \\
(0.01)\end{array}$ \\
\hline 1995-2003 & $\begin{array}{c}0.008 \\
(0.01)\end{array}$ & $\begin{array}{l}-0.579^{* *} \\
(0.28)\end{array}$ & $\begin{array}{c}-0.143 \\
(0.22)\end{array}$ & $\begin{array}{c}-0.029 \\
(0.10)\end{array}$ & $\begin{array}{l}0.053^{* * *} \\
(0.01)\end{array}$ & $\begin{array}{l}0.033^{* * *} \\
(0.01)\end{array}$ & $\begin{array}{l}0.961^{* * *} \\
(0.01)\end{array}$ & 0.01 & $\begin{array}{c}4.90 \\
(0.18)\end{array}$ \\
\hline 2004-2013 & $\begin{array}{c}-0.002 \\
(0.02)\end{array}$ & $\begin{array}{c}-0.480 \\
(0.41)\end{array}$ & $\begin{array}{c}-0.231 \\
(0.39)\end{array}$ & $\begin{array}{c}-0.182 \\
(0.13)\end{array}$ & $\begin{array}{l}0.419^{* * *} \\
(0.02)\end{array}$ & $\begin{array}{l}0.080^{* * * *} \\
(0.02)\end{array}$ & $\begin{array}{l}0.905^{* * *} \\
(0.02)\end{array}$ & 0.27 & $\begin{array}{c}3.52 \\
(0.32)\end{array}$ \\
\hline \multicolumn{10}{|l|}{ France } \\
\hline 1995-2013 & $\begin{array}{l}0.044^{* * *} \\
(0.01)\end{array}$ & $\begin{array}{c}0.240 \\
(0.25)\end{array}$ & $\begin{array}{c}-0.181 \\
(0.18)\end{array}$ & $\begin{array}{c}0.054 \\
(0.09)\end{array}$ & $\begin{array}{l}0.281^{* * *} \\
(0.01)\end{array}$ & $\begin{array}{l}0.077^{* * *} \\
(0.01)\end{array}$ & $\begin{array}{l}0.909^{* * *} \\
(0.01)\end{array}$ & 0.24 & $\begin{array}{c}2.10 \\
(0.55)\end{array}$ \\
\hline 1995-2003 & $\begin{array}{l}0.031^{* *} \\
(0.02)\end{array}$ & $\begin{array}{c}-0.411 \\
(0.31)\end{array}$ & $\begin{array}{c}-0.293^{*} \\
(0.16)\end{array}$ & $\begin{array}{c}-0.081 \\
(0.11)\end{array}$ & $\begin{array}{l}0.125^{* * *} \\
(0.02)\end{array}$ & $\begin{array}{l}0.096^{* * *} \\
(0.02)\end{array}$ & $\begin{array}{l}0.822^{* * *} \\
(0.05)\end{array}$ & 0.07 & $\begin{array}{c}6.55^{*} \\
(0.09)\end{array}$ \\
\hline 2004-2013 & $\begin{array}{l}0.051^{* * *} \\
(0.02)\end{array}$ & $\begin{array}{c}-0.694 \\
(0.44)\end{array}$ & $\begin{array}{c}0.524 \\
(0.80)\end{array}$ & $\begin{array}{c}-0.213 \\
(0.16)\end{array}$ & $\begin{array}{l}0.707^{* * *} \\
(0.02)\end{array}$ & $\begin{array}{l}0.071^{* * *} \\
(0.01)\end{array}$ & $\begin{array}{l}0.908^{* * *} \\
(0.02)\end{array}$ & 0.48 & $\begin{array}{c}6.71^{*} \\
(0.08)\end{array}$ \\
\hline \multicolumn{10}{|l|}{ Germany } \\
\hline 1995-2013 & $\begin{array}{c}0.009 \\
(0.02)\end{array}$ & $\begin{array}{l}1.065^{* * *} \\
(0.37)\end{array}$ & $\begin{array}{c}-0.113 \\
(0.55)\end{array}$ & $\begin{array}{l}0.474 * * * \\
(0.13)\end{array}$ & $\begin{array}{l}0.362^{* * *} \\
(0.02)\end{array}$ & $\begin{array}{l}0.083^{* * *} \\
(0.01)\end{array}$ & $\begin{array}{l}0.916^{* * *} \\
(0.01)\end{array}$ & 0.17 & $\begin{array}{l}24.75^{* * *} \\
(0.00)\end{array}$ \\
\hline 1995-2003 & $\begin{array}{c}-0.009 \\
(0.03)\end{array}$ & $\begin{array}{c}-0.853 \\
(0.67)\end{array}$ & $\begin{array}{c}-1.361 \\
(1.42)\end{array}$ & $\begin{array}{l}0.354^{*} \\
(0.19)\end{array}$ & $\begin{array}{l}0.163^{* * *} \\
(0.02)\end{array}$ & $\begin{array}{l}0.090^{* * *} \\
(0.03)\end{array}$ & $\begin{array}{l}0.909^{* * *} \\
(0.02)\end{array}$ & 0.05 & $\begin{array}{c}4.94 \\
(0.18)\end{array}$ \\
\hline 2004-2013 & $\begin{array}{c}0.008 \\
(0.02)\end{array}$ & $\begin{array}{c}0.384 \\
(0.46)\end{array}$ & $\begin{array}{c}0.415 \\
(0.60)\end{array}$ & $\begin{array}{l}0.357^{* *} \\
(0.18)\end{array}$ & $\begin{array}{l}0.541^{* * *} \\
(0.02)\end{array}$ & $\begin{array}{l}0.091^{* * *} \\
(0.01)\end{array}$ & $\begin{array}{l}0.894^{* * *} \\
(0.01)\end{array}$ & 0.35 & $\begin{array}{c}5.36 \\
(0.15)\end{array}$ \\
\hline \multicolumn{10}{|l|}{ Netherlands } \\
\hline 1995-2013 & $\begin{array}{c}0.018 \\
(0.01)\end{array}$ & $\begin{array}{l}0.316 \\
(0.26)\end{array}$ & $\begin{array}{c}0.114 \\
(0.33)\end{array}$ & $\begin{array}{c}0.072 \\
(0.08)\end{array}$ & $\begin{array}{l}0.193^{* * *} \\
(0.01)\end{array}$ & $\begin{array}{l}0.081^{* * *} \\
(0.01)\end{array}$ & $\begin{array}{l}0.907^{* * *} \\
(0.01)\end{array}$ & 0.19 & $\begin{array}{c}2.30 \\
(0.51)\end{array}$ \\
\hline 1995-2003 & $\begin{array}{c}0.000 \\
(0.01)\end{array}$ & $\begin{array}{c}-0.278 \\
(0.28)\end{array}$ & $\begin{array}{c}0.197 \\
(0.36)\end{array}$ & $\begin{array}{c}-0.101 \\
(0.08)\end{array}$ & $\begin{array}{l}0.103^{* * *} \\
(0.01)\end{array}$ & $\begin{array}{l}0.154^{* * *} \\
(0.03)\end{array}$ & $\begin{array}{l}0.599^{* * *} \\
(0.09)\end{array}$ & 0.09 & $\begin{array}{c}3.35 \\
(0.34)\end{array}$ \\
\hline 2004-2013 & $\begin{array}{c}0.016 \\
(0.02)\end{array}$ & $\begin{array}{l}0.840^{*} \\
(0.50)\end{array}$ & $\begin{array}{c}0.856 \\
(0.60)\end{array}$ & $\begin{array}{c}-0.116 \\
(0.15)\end{array}$ & $\begin{array}{l}0.686^{* * *} \\
(0.02)\end{array}$ & $\begin{array}{l}0.074^{* * *} \\
(0.01)\end{array}$ & $\begin{array}{l}0.915^{* * *} \\
(0.02)\end{array}$ & 0.46 & $\begin{array}{c}5.85 \\
(0.12)\end{array}$ \\
\hline \multicolumn{10}{|l|}{ Sweden } \\
\hline 1995-2013 & $\begin{array}{l}0.040 * * * \\
(0.01)\end{array}$ & $\begin{array}{l}-0.460^{* *} \\
(0.23)\end{array}$ & $\begin{array}{l}-0.627^{* *} \\
(0.29)\end{array}$ & $\begin{array}{l}-0.355^{* * *} \\
(0.09)\end{array}$ & $\begin{array}{l}0.370^{* * *} \\
(0.01)\end{array}$ & $\begin{array}{l}0.093 * * * \\
(0.01)\end{array}$ & $\begin{array}{l}0.895^{* * *} \\
(0.01)\end{array}$ & 0.28 & $\begin{array}{l}23.64 * * * \\
(0.00)\end{array}$ \\
\hline 1995-2003 & $\begin{array}{l}0.016 \\
(0.02)\end{array}$ & $\begin{array}{l}-1.237^{* * * *} \\
(0.28)\end{array}$ & $\begin{array}{c}-0.386 \\
(0.34)\end{array}$ & $\begin{array}{l}-0.533^{* * * *} \\
(0.10)\end{array}$ & $\begin{array}{l}0.245^{* * *} \\
(0.01)\end{array}$ & $\begin{array}{l}0.152^{* * *} \\
(0.04)\end{array}$ & $\begin{array}{l}0.751^{* * *} \\
(0.06)\end{array}$ & 0.21 & $\begin{array}{l}38.23^{* * *} \\
(0.00)\end{array}$ \\
\hline 2004-2013 & $\begin{array}{c}0.033 \\
(0.02)\end{array}$ & $\begin{array}{l}0.163 \\
(0.49)\end{array}$ & $\begin{array}{c}-0.040 \\
(0.58)\end{array}$ & $\begin{array}{l}0.120 \\
(0.21)\end{array}$ & $\begin{array}{l}0.688^{* * *} \\
(0.02)\end{array}$ & $\begin{array}{l}0.066^{* * *} \\
(0.02)\end{array}$ & $\begin{array}{l}0.927^{* * *} \\
(0.02)\end{array}$ & 0.45 & $\begin{array}{c}0.52 \\
(0.92)\end{array}$ \\
\hline \multicolumn{10}{|l|}{ Switzerland } \\
\hline $1995-2013$ & $\begin{array}{l}0.029 * * * \\
(0.01)\end{array}$ & $\begin{array}{c}-0.100 \\
(0.12)\end{array}$ & $\begin{array}{l}0.756^{* *} \\
(0.32)\end{array}$ & $\begin{array}{c}0.003 \\
(0.11)\end{array}$ & $\begin{array}{l}0.132^{* * *} \\
(0.01)\end{array}$ & $\begin{array}{l}0.118^{* * *} \\
(0.02)\end{array}$ & $\begin{array}{l}0.864^{* * *} \\
(0.02)\end{array}$ & 0.08 & $\begin{array}{c}5.80 \\
(0.12)\end{array}$ \\
\hline 1995-2003 & $\begin{array}{r}0.009 \\
(0.01)\end{array}$ & $\begin{array}{l}-0.368^{* *} \\
(0.17)\end{array}$ & $\begin{array}{l}1.095^{* * *} \\
(0.30)\end{array}$ & $\begin{array}{c}-0.122 \\
(0.14)\end{array}$ & $\begin{array}{l}0.055^{* * *} \\
(0.01)\end{array}$ & $\begin{array}{l}0.028^{* * *} \\
(0.01)\end{array}$ & $\begin{array}{l}0.970^{* * *} \\
(0.01)\end{array}$ & 0.02 & $\begin{array}{l}17.78^{* * *} \\
(0.00)\end{array}$ \\
\hline 2004-2013 & $\begin{array}{l}0.036^{* * *} \\
(0.01)\end{array}$ & $\begin{array}{c}0.012 \\
(0.21)\end{array}$ & $\begin{array}{c}0.092 \\
(0.78)\end{array}$ & $\begin{array}{c}0.071 \\
(0.17)\end{array}$ & $\begin{array}{l}0.306^{* * *} \\
(0.02)\end{array}$ & $\begin{array}{l}0.136^{* * *} \\
(0.03)\end{array}$ & $\begin{array}{l}0.836^{* * *} \\
(0.03)\end{array}$ & 0.21 & $\begin{array}{c}0.19 \\
(0.98)\end{array}$ \\
\hline \multicolumn{10}{|l|}{ UK } \\
\hline 1995-2013 & $\begin{array}{l}0.035^{* * *} \\
(0.01)\end{array}$ & $\begin{array}{l}0.881^{* * * *} \\
(0.23)\end{array}$ & $\begin{array}{c}-0.136 \\
(0.18)\end{array}$ & $\begin{array}{c}0.073 \\
(0.10)\end{array}$ & $\begin{array}{l}0.451^{* * *} \\
(0.01)\end{array}$ & $\begin{array}{l}0.068^{* * *} \\
(0.01)\end{array}$ & $\begin{array}{l}0.923^{* * *} \\
(0.01)\end{array}$ & 0.30 & $\begin{array}{l}16.95^{* * * *} \\
(0.00)\end{array}$ \\
\hline 1995-2003 & $\begin{array}{c}0.019 \\
(0.01)\end{array}$ & $\begin{array}{c}0.343 \\
(0.28)\end{array}$ & $\begin{array}{c}0.012 \\
(0.19)\end{array}$ & $\begin{array}{l}0.076 \\
(0.10)\end{array}$ & $\begin{array}{l}0.255^{* * *} \\
(0.02)\end{array}$ & $\begin{array}{l}0.088^{* * *} \\
(0.02)\end{array}$ & $\begin{array}{l}0.882^{* * * *} \\
(0.03)\end{array}$ & 0.16 & $\begin{array}{c}2.40 \\
(0.49)\end{array}$ \\
\hline 2004-2013 & $\begin{array}{l}0.031^{*} \\
(0.02)\end{array}$ & $\begin{array}{c}-0.119 \\
(0.35)\end{array}$ & $\begin{array}{l}0.056 \\
(0.33)\end{array}$ & $\begin{array}{c}-0.324^{* *} \\
(0.14)\end{array}$ & $\begin{array}{l}0.861^{* * *} \\
(0.02)\end{array}$ & $\begin{array}{l}0.042^{* * *} \\
(0.01)\end{array}$ & $\begin{array}{l}0.955^{* * *} \\
(0.01)\end{array}$ & 0.46 & $\begin{array}{c}5.69 \\
(0.13)\end{array}$ \\
\hline
\end{tabular}


Table 4. Augmented multifactor yield curve results.

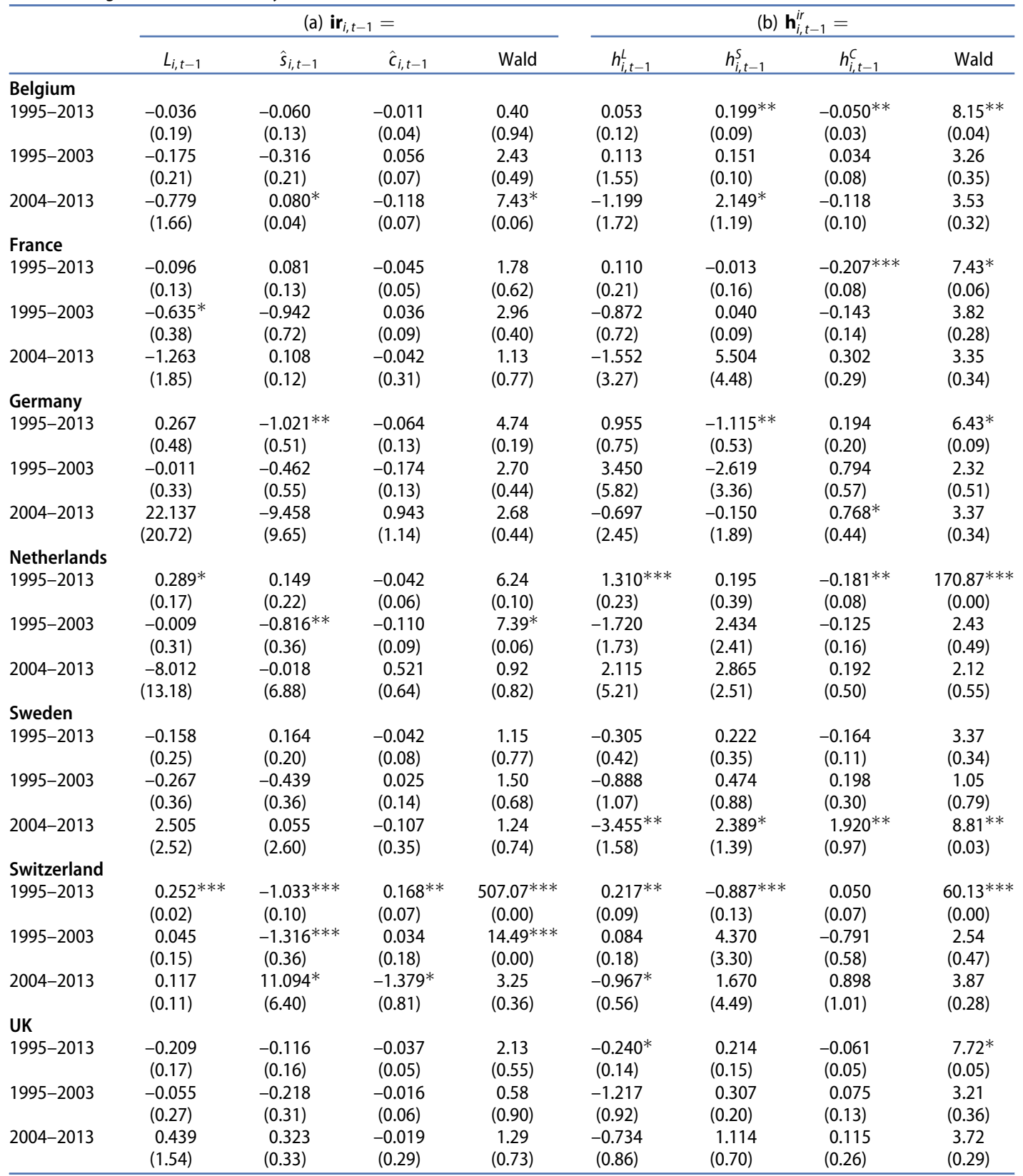

Notes. Table 4 reports the results from the Dielbold et al. (2006) yield curve model.

$*^{* *},{ }^{* * *}$ indicate significance at the $10 \%, 5 \%$ and $1 \%$ levels, respectively.. 